\section{Rebel governance in de facto states}

\author{
Adrian Florea 1
}

University of Glasgow, UK
European Journal of International Relations 2020, Vol. 26(4) 1004-103। (C) The Author(s) 2020

(c) (i)

Article reuse guidelines: sagepub.com/journals-permissions DOI: 10.1 I77/1354066/209|948। journals.sagepub.com/home/ejt

@SAGE

\begin{abstract}
De facto states, such as Somaliland (Somalia), are unrecognized separatist enclaves that display characteristics of statehood but lack an international legal status. To acquire domestic and external legitimacy, these actors engage in a wide range of governance practices: they set up military and police forces; executive, legislative, and judicial branches; hospitals; schools; banks; or social security networks. In spite of the obvious gains that can be accrued through the establishment of a complex governance architecture, de facto states exhibit great variation in the range of statelike institutions that they build: some, like Luhansk People's Republic (Ukraine), put together a rudimentary governance apparatus, while others, like Transnistria (Moldova), manage to construct a complex system of rule. What explains the variation in governance practices across these separatist enclaves? Using original data on governance institutions across all de facto states (1945-2016), this study offers an empirical examination of the key factors that shape separatists' incentives to supply governance. The findings reveal that de facto state separatists are less likely to provide governance when they have access to lootable mineral resources but are more likely to do so when they receive external military support, when peacekeepers are present, when they have access to relatively immobile assets, when they adopt a Marxist ideology, and when they control the territory for a long time. The findings help us better understand the conditions under which armed nonstate actors supplant sovereign states as de facto authorities and successfully institutionalize their rule.
\end{abstract}

\title{
Keywords
}

de facto states, secession, rebel governance, civil war, sovereignty, territoriality

\section{Corresponding author:}

Adrian Florea, School of Social and Political Sciences, College of Social Sciences, University of Glasgow, 9 Lilybank Gardens, 403, Glasgow GI 2 8QF, UK.

Email: adrian.florea@glasgow.ac.uk 


\section{Introduction}

Before 2009, visitors traveling into northeast Sri Lanka would have come across a string of internal "border" checkpoints that did not appear on any official map because they were controlled by the Liberation Tigers of Tamil Eelam (LTTE). From Kilinochchi to Trincomalee, the heavily enforced checkpoints regulated the entrance of people and goods into Tamil Eelam - a de facto state where Tamil separatists established parallel structures of governance. In 2009, the Sri Lankan army launched a major offensive at the end of which the LTTE was decimated and the de facto state vanished. Tamil Eelam is not an isolated example of a separatist group ruling autonomously over parts of a sovereign country's territory and engaging in statelike activities. In fact, de facto states have been a constant presence in the post-1945 international environment (Florea, 2014). Some, like Northern Cyprus and Somaliland, have been around for several decades while others, like Donetsk People's Republic (Ukraine) or Cyrenaica/Eastern Libya, are more recent creations. De facto states straddle the territory between banditry and statebuilding (Ahram, 2019) and conjure up two images: (i) one of semianarchic spaces controlled by ruthless insurgents who are predatory and operate at the whim of great or regional powers and (ii) another of functional entities that command domestic legitimacy and establish complex governance structures. To outsiders, de facto state leaders may look like opportunistic warlords; to locals, they embrace the mantra of state builders who provide order, organize local affairs, and supplant the sovereign government as the rulemaking authority (Pegg, 1998).

What separates de facto states from other types of nonstate violence monopolists is their goal of independence and their relative success at constructing a functional apparatus of statehood. Having secured military control over a defined territory that legally belongs to a recognized nation-state, de facto state leaders regularly perform a wide range of governance activities: they set up parallel governmental and administrative structures, establish alternative institutions for property rights enforcement and dispute adjudication, engage in regularized extraction/taxation, and provide public goods, such as health, education, or social security services, to the local population. Despite coordination and enforcement costs - agreeing over and implementing a rule-based governance strategy is a costly undertaking - governance provided by separatists in de facto states yields various payoffs: it bolsters their legitimacy with domestic and foreign audiences (Coggins, 2014; Griffiths, 2016), facilitates recruitment and resource mobilization, signals commitment to local rule, and contributes to the internationalization of the dispute.

Although the expected gains that can be accrued through the establishment of a governance architecture are obvious, de facto states display great variation in the range of statelike institutions that they build: some, like the self-declared Luhansk People's Republic in Ukraine, cobbled together a rudimentary apparatus of control, while others, like Transnistria in Moldova, managed to construct an advanced system of separate rule. What explains the variation in governance practices across these actors that share similar objectives? Why don't all facto states build more governance institutions when these institutions would likely increase their domestic and international legitimacy, or more broadly, their claims to independent statehood? 
Relying on originally collected data for all de facto states during the post-World War II period (1945-2016), this study argues that the observed variability in governance activities across breakaway enclaves is shaped by the nature of the threat environment in which separatists operate, the organizational structure of the separatist movement, and the type of resource endowments available to de facto state leaders. The article identifies two key factors that are expected to alter the threat environment and, thus, to affect separatists' governance decisions: external military support and the presence of peacekeepers. External military support helps de facto state leaders maintain mobilization against the parent state, reduces the level of threat, and can motivate them to focus more extensively on governing the territory under their control. Peacekeepers can also critically affect separatists' threat perceptions. While peacekeepers' main role is to prevent the resumption of violence, their presence effectively insulates the enclave from the parent state and helps separatists cement their authority. The organizational structure of the insurgency - whether it is unitary or fragmented - is critical for the viability of alternative structures of governance in the long term. Fragmentation can divert oftenscarce resources toward factional infighting rather than the institutionalization of a governance apparatus. The sustainability of a functional governance system across de facto states also depends on the nature of resource endowments available to insurgents. In the presence of relatively immobile assets under their control, separatists will likely be motivated to engage in more extensive governance practices. However, when they have access to lootable mineral resources, separatists will likely be disincentivized to embark on governance activities.

Empirical analysis provides mixed support for the theoretical expectations. External military support seems to only affect the establishment of certain types of governance institutions, specifically political institutions such as an executive, legislature, or court system. The presence of peacekeepers is positively related to the whole range of governance institutions. Rebel movement fragmentation appears to affect (negatively) only the institutionalization of regularized taxation. Immobile assets display a positive impact on all types of governance institutions, particularly on political and extractive/taxation institutions. Access to expropriable mineral resources emerges as a strong inhibitor of institutionalized rebel rule. The results also reveal that governance in de facto states is likely to be more extensive when separatists embrace a Marxist/communist ideology and when they rule over the territory for a long period of time. Overall, the findings contribute to growing research on governance by armed nonstate actors by identifying the conditions under which these actors are incentivized to supply governance. More broadly, the analysis helps us better grasp rebels' incentives toward organized rule vs. predation and enhances our understanding of authority fragmentation in civil war.

The remainder of the article is organized as follows. The first part provides a conceptual definition for rebel governance and discusses the logical underpinnings of governance provision in de facto states. The theoretical discussion produces a series of expectations that are then tested with originally collected data on all de facto states between 1945 and 2016. The empirical analysis is followed by an examination of the statistical and substantive significance of the main findings. Finally, the last section elaborates on the theoretical and practical importance of the key results. 


\section{The logic of rebel governance in de facto states}

Rebels are conventionally viewed as violence entrepreneurs who fight against the state (or against internal competitors) and engage in selective or indiscriminate violence against civilians (Kalyvas, 2006). Less common is the image of the rebel who decides to "settle down, wear a crown, and replace [internal] anarchy with government" (Olson, 1993: 568). While the logic of violence in civil war has received extensive attention, the logic of rebel governance in internal conflicts has been less thoroughly investigated. This is surprising given that rebel governance is fairly common across rebellions spanning multiple regions and time periods. The governance activities conducted by Latin American insurgencies, such as FARC (Colombia), FMLN (El Salvador), or Sendero Luminoso (Peru), are well documented (Arjona, 2016; Weinstein, 2007; WickhamCrowley, 1987). There is also abundant information on the state-building practices of various rebel movements throughout Africa (Mampilly, 2011; Reno, 2011), Southeast Asia (Hashim, 2013), the Middle East (Berti, 2015; Pearlman, 2011), or the post-Soviet space (Caspersen, 2012; Hill, 2012; Toal, 2017).

Existing studies view rebel governance through the prism of activities aimed at implementing collectively binding rules and providing public goods in insurgent-held territory (Arjona et al., 2015; Huang, 2016a). Mampilly (2011:17) states that a rebel organization engages in effective governance when it (a) exercises a violent monopoly over an area and is able to "develop a force capable of policing the population" living in that area; (b) develops a dispute resolution mechanism, "either through a formal judicial structure or through an ad-hoc system"; and (c) displays "capacity to provide other public goods beyond security." The burgeoning research on rebel governance overwhelmingly concentrates on the redistributive aspect of insurgents' behavioral repertoire. Current large- $N$ and qualitative studies of rebel rule mainly seek to explain public goods provision in rebel-held territory and the processes through which redistributive rebel activities impact conflict outcomes, such as duration, termination, post-war democratization, or civilian victimization (Arjona, 2016; Florea, 2017; Heger and Jung, 2017; Huang, 2016a; Stewart, 2018). However, the act of "governing" observed across de facto states and other armed nonstate actors pursuing different objectives (such as government overthrow) goes beyond redistribution/public goods provision and involves a broader array of institutional practices (Clunan and Trinkunas, 2010; Risse, 2011). With that in mind, this study adopts a more extensive view of rebel governance which includes the entire range of political, redistributive, and extractive institutions through which insurgents regulate social, economic, and political life in the territory under their control. ${ }^{1}$ The conceptualization of rebel governance adopted herein includes the entire spectrum of rebel activities that are functionally equivalent to state building: political organization (establishing executive, legislative, or judicial institutions); redistribution (providing public goods); and, extraction (engaging in regularized taxation).

Rebel governance practices are quite diverse. Many rebel groups engage in some form of regularized extraction/taxation and, thus, appropriate an important function of sovereign statehood. Various insurgents movements, such as the Patriotic Union of Kurdistan (Natali, 2010), the Rassemblement Congolais pour la Democratie (de la 
Sierra, 2020) or, more recently, the Islamic State of Iraq and al-Sham (Revkin, 2020), impose(d) taxes on property, incomes, export and import of goods, services, trade activity, vehicle and population transit, remittances, or mineral output. Other rebel groups, such as the Kachin Independence Army in Burma/Myanmar (Berg and Van Houtum, 2003) set up parallel systems of government with ministries, police and border forces, prisons, schools, and hospitals. Still other insurgents, such as those in the Puntland region of Somalia (Nalla, 2010), developed complex legal systems and dispute resolution mechanisms.

What is distinctive about de facto states is the expectation that they would display a complex governance architecture. Unlike other types of armed nonstate organizations who can employ governance more strategically, or more selectively, de facto state leaders would presumably embark on an extensive institutionalization of their rule. This assumption derives from two key characteristics that set de facto states apart from other types of armed nonstate actors: violence monopoly/territorial control and the goal of independence. On the one hand, violence monopolists have rational incentives to become stationary in order to maximize the benefits of self-rule (Olson, 1993). On the other hand, rebels seeking independence need to demonstrate to both domestic and international audiences a capacity for successful rule in order to gain and maintain legitimacy (Cunningham, 2015; Griffiths, 2016; Stewart, 2018). De facto states supplant sovereign governments as acting authorities over the claimed territory but their legitimacy ultimately depends on their ability to maintain order, administer justice, adjudicate disputes, provide public services (such as roads, schools, or hospitals), and coordinate formal or informal institutions for the organization of local affairs. Essentially, their legitimacy - being accepted as the rightful authority of the land — comes down to their ability and willingness to provide effective governance. By constructing a functional governance structure, de facto state leaders credibly commit to uphold their end of the social contract, ensure voluntary compliance with their rule, and signal to international audiences their capacity to organize domestic affairs and survive separately from the parent state.

Across many de facto states, governance is indeed deployed quite extensively. For instance, Somaliland, a de facto state that emerged in 1991 after the collapse of the Barre regime in Somalia, has gradually built the institutional architecture of a sovereign state. The self-declared republic has its own government, legislature, court systems, and police. The enclave engages in regularized taxation, provides public services such as health and education, conducts trade with international partners, and even boasts a separate central bank that issues currency (the Somaliland shilling). During its separate existence spanning almost three decades, the region has been more stable than the sovereign state it still legally belongs to (Somalia).

In other cases, however, de facto state leaders have been less successful at implementing a functional governance system. For example, the Liberation Tigers (LTTE) who controlled the now defunct Tamil Eelam in Northeast Sri Lanka between 1984 and 2009 did display a separate legal system comprising a network of district courts and appeal courts. Yet, the LTTE never provided health care or educational services in the territory under its control, nor did it effectively coordinate local productive activities (Hashim, 2013). More recently, separatists in the self-proclaimed Luhansk People's 
Republic (LPR) in Eastern Ukraine (2014-) have been struggling to put together even basic structures of statehood (Toal, 2017). Nominally, LPR has its own government, parliament, and courts, but these institutions are hardly functional: the government is riven by rivalry among former rebel commanders, the parliament is little more than a rubber-stamp assembly that convenes irregularly, and the newly established local courts have yet to adopt a civil code. These examples from de facto states across different regions and time periods illustrate bewildering variability in governance activities: some are quite successful at institutionalizing a statelike system of self-rule while others engage in minimal governance. What might explain this variation?

Building on the recent literature on de facto states and rebel organizational behavior, this study argues that de facto state leaders' incentives to provide governance extensively or in a more limited way are likely shaped by the nature of the threat environment in which they operate, the organizational structure of the separatist movement, and the type of resource endowments present in the breakaway enclaves. The next section discusses the processes through which these factors alter the motivation of separatists to build more or less developed governance systems.

\section{Threat environment}

Although de facto states control territory and aspire to become independent, their existence is inherently precarious and their survival ultimately depends on their ability to successfully mobilize against the central government. The ability and willingness of de facto state leaders to institutionalize an elaborate governance apparatus will likely be affected by the level of threat to their violence monopoly. Where the threat to separatists' violence monopoly is severe, they will be less incentivized to construct a sophisticated governance architecture. By contrast, where the threat to their grip on territory is less acute, they will likely be more invested in developing a comprehensive governance system. The recent literature on de facto states (Caspersen, 2012; Florea, 2017; Keating, 2018; Lynch, 2004; Toal, 2017) suggests that two key factors fundamentally shape the threat environment in which they operate and, hence, their ability to secure a violence monopoly: the extent of external military support from third parties and the presence of peacekeepers on their territory.

External military support provided by an external patron can offer de facto state leaders great latitude in maintaining the mobilizational base of their movement and directing material resources toward governance activities (San-Akca, 2016). Foreign military assistance can come in different forms: small arms, communication technologies, logistics, military hardware, military personnel, professional trainers, safe havens (Byman, 2005). Enforcing order, administering justice, forming popular assemblies, setting up a system of regularized taxation and public administration, operating schools and hospitals, managing local economic affairs, cultivating legitimacy through symbolic practices (such as military parades or monuments dedicated to rebel "warriors") necessitate a hefty "governance chest." Running an alternative government bureaucracy is an onerous task requiring substantial funds that are separate from those allocated for prosecuting the insurgency. External military assistance-especially assistance credibly offered to separatists on a regular basis - can facilitate the reallocation of resources 
toward governance activities. Under the protective umbrella of an external backer, separatists are likely to be more successful at consolidating their rule and forging a social contract with the local population. Hence, external military support can translate into powerful incentives to build governance institutions.

The post-Soviet surviving de facto states-Transnistria (Moldova); Abkhazia and South Ossetia (Georgia); Nagorno-Karabakh (Azerbaijan) — vividly illustrate the key role of foreign military support for the development of statelike institutions. Under the protection of external backers (Russia in the case of Transnistria, Abkhazia, and South Ossetia; Armenia in the case of Nagorno-Karabakh), all these enclaves managed to construct a functional statelike apparatus with political, extractive, and redistributive institutions (Blakkisrud and Kolsto, 2011; Caspersen, 2012). Beyond the post-Soviet space, Turkey has been instrumental for the state-building process in Northern Cyprus (Ker-Lindsay, 2012) and, more recently, extensive military assistance from the UAE has been key to the development of a parallel government in Cyrenaica/Eastern Libya (Ahram, 2019). While external military support is expected to positively affect the broad governance process across de facto states, its impact on the types of governance institutions established by separatists is likely to be more variegated. Studies on statebuilding processes across the post-Soviet de facto states, for instance, suggest that military assistance from a patron state is most likely to influence the development of political and redistributive institutions (Caspersen, 2012; Lynch, 2004). Decisions regarding the extent of regularized taxation (extraction) seem to have been taken by separatists independently of external military support. ${ }^{2}$ Therefore, the first expectation is that external military support will positively affect the overall number of governance institutions, but more so political and redistributive institutions rather than extractive institutions.

Peacekeepers present on the territory of de facto states can also critically alter the threat environment in which separatists operate. While peacekeepers are mainly introduced to prevent the resumption of violent conflict, their presence effectively insulates the territory from the parent state and can help separatists consolidate a violence monopoly. Peacekeeping operations often function as military and political buffers and can, thus, provide fertile ground for the establishment or consolidation of alternative structures of authority (Fortna, 2008). According to Beardsley et al. (2015), peacekeeping operations may allow nonstate actors to bolster their power. Specifically, peacekeepers "may allow nonstate actors to gain strength and legitimacy and thus constitute an even greater future threat to the state whether some form of accord is not reached" (Beardsley and Gleditsch, 2015: 67). Thus, with peacekeepers present, one might expect de facto leaders to be shielded from external threats and to direct more resources toward governance activities.

Just like external military support, the impact of peacekeepers on the establishment of governance institutions across de facto states is unlikely to be uniform. Peacekeepers may open up the space for separatists to develop their political institutions and may directly or indirectly assist with the provision of public goods, such as security, hospitals, and schools. For example, the United Mission in the Sudan (UNMIS; 2005-2011), helped provide security and a space for cooperation between humanitarian agencies and the South Sudanese separatists regarding the provision of health and education services 
for the local population (Podder, 2014). At the same time, the effect of peacekeeping missions on extractive institutions might be less pronounced. De facto state leaders could be less incentivized to build extractive institutions when peacekeepers facilitate, directly or indirectly, the provision of public services such as security, health, and education. The data on governance institutions established by de facto states will be able to elucidate whether the presence of peacekeepers has varying effects on the types of governance institutions established by these resilient nonstate actors.

\section{Organizational structure of the insurgency}

The organizational structure of de facto states is another key factor that can impact separatists' incentives to build governance institutions. The internal characteristics of an insurgency (whether it is cohesive/unitary or fragmented) can be an important source of variability in rebel governance. Intuitively, cohesive/unitary rebel movements should be more successful at institutionalizing alternative orders. A cohesive movement typically "enjoys the organizational power to mobilize mass participation, enforce strategic discipline, and contain disruptive content." By contrast, a fragmented movement "lacks the leadership, institutions, and collective purpose to coordinate and constrain its members" (Pearlman, 2011: 2). Rebel fragmentation is common in civil wars (Bakke et al., 2012) and has been found to impact various conflict processes, such as escalation from nonviolence to violence, the likelihood of peace settlements, or internecine violence (Seymour et al., 2016).

Fragmentation can substantially impair rebels' ability to fulfill classic functions associated with government. Where political or military authority within a movement is highly contested, valuable resources might be diverted toward factional infighting than toward governance provision. Conversely, when there is little contention about the locus of nonstate authority, rebels might be better positioned to regulate socioeconomic and political affairs in areas under their control. Fragmentation is particularly pernicious when there is no external patron to compensate for resources expended on internal strife. For example, fission within the rebel movement was undoubtedly a key driver behind the unravelling of the Chechen insurgency in 1999. After the rebels drove Russian troops out of the republic in August 1996, internal rivalries sapped the organizational strength of the insurgency. Fierce infighting between warlords like Shamil Basayev and Aslan Maskhadov took precedence over state-building activities. The consequences were felt immediately: by early 1999, Chechnya was characterized by almost complete dismantling of institutions, "loss of control over the means of violence, failure to incorporate armed groups in the state, and radicalization of Islamic discourse" (Zurcher, 2007: 86).

Intra-movement competition can markedly shape rebels' decision to supply governance. Hegemonic groups can rely on their monopolistic position to institutionalize a governance system, strengthen their legitimacy with the local population, and deter new entrants into the local marketplace of authority. Akcinaroglu and Tokdemir (2018) claim that, given the costs of providing governance, armed groups that control territory monopolistically will be more likely to invest in positive reputation in their communities, through the provision of goods and services, because the risks on their investment will be lower. By contrast, groups confronted with internal rivals will be less inclined, or less able, to provide governance. According to Metelits (2010: 12), "when an insurgent 
group does not confront competition for resources, it can more efficiently mobilize popular support, collecting resources and recruiting cadres to gain autonomy from the state and potential rivals."

All these rationales converge to suggest that fragmentation can have pernicious effects on separatists' ability to build governance institutions. Yet, a functional disaggregation of these institutions might indicate potentially variable effects of fragmentation on the kinds of governance institutions constructed by separatists in de facto states. While a negative impact of intra-group rivalry on extractive and redistributive institutions is intuitive and clearly visible across recent cases (e.g., Cyrenaica/Eastern Libya or Luhansk People's Republic in Ukraine), the effect of fragmentation on the development of political institutions is less obvious. At first sight, one might expect intra-rebel rivalry to reduce insurgents' ability to set up or maintain political systems, with functional executive, legislative, or judicial branches, for instance. Upon closer scrutiny, groups faced with multiple internal competitors, such as the LTTE in Sri Lanka during the 1980s, were quite adept at developing political institutions (Hashim, 2013). The disaggregated data on the types of governance institutions across de facto states will allow us to untangle the relationship between fragmentation and rebel governance.

\section{Resource endowments}

De facto states perform statelike activities inconsistently and illustrate that violence monopolies or shared rebel objectives are imperfect predictors of nonstate governance. What also seems to matter is the type of resource endowments available to separatists, more precisely the nature of local assets and mineral resources located in their territory. Where separatists control relatively immobile local assets, such as industrial or agricultural assets, they will likely anticipate constant revenue streams and will have a vested interest in becoming stationary and supporting productive economic activities. The assets located in rebel-held territory can drastically change insurgents' approach to governance because the anticipated revenue from the exploitation of relatively immobile assets is likely to shift the equilibrium strategy from plunder to governance (de la Sierra, 2020). In the presence of immobile assets, it is in the best interest of separatists to limit forceful extraction and encourage economic activity in order to maximize taxable output (Sabates-Wheeler and Verwimp, 2014). To maximize extraction/taxation, though, rebel rulers have an encompassing interest to strike a social bargain with the local population, one that typically involves redistribution/public goods provision (Olson, 1993). ${ }^{3}$ Hence, asset specificity is likely to directly affect rebel extraction/taxation and redistribution/public goods provision.

In the case of de facto states, agricultural or industrial assets have typically been established anew by separatists after they secured territorial control or have been inherited from parent states after the latter lost control of the disputed enclave. Somaliland is an example of a de facto state with a fairly robust agricultural sector comprising primarily of livestock production. Livestock is crucial for the viability of the breakaway territory as it represents about $60 \%$ of Somaliland's GDP and more than $75 \%$ of its exports (Muhumed and Yonis, 2018). An example of a de facto state with a welldeveloped industrial infrastructure inherited from the parent state is Transnistria, a de facto state that separated from Moldova in the aftermath of Soviet Union's collapse. 
During the Soviet times, the bulk of Moldova's heavy industry was concentrated in Transnistria. After the enclave's de facto separation in 1991, Transnistrian separatists retained control over a large industrial complex. Since then, this industrial infrastructure has consistently generated more than half of the region's GDP (Calus, 2013). Four large enterprises operate in the breakaway statelet: Moldova Steel Works (MSW) in Ribnita, which "by 2000 was exporting production worth $\$ 150$ million annually, including $\$ 70$ million to the United States" (Hill, 2012: 98) and which provides about $60 \%$ of Transnistria's exports and "somewhere around 50\% of its tax revenues" (Blakkisrud and Kolsto, 2011: 189); Cuciurgani power plant, which provides all the enclave's energy needs, and even meets about $50 \%$ of Moldova's electricity demand; ${ }^{4}$ Ribnita cement plant, which exports most of its output to Russia; and the Sheriff conglomerate, which owns a TV channel, textile factory, mobile network, supermarket chain, modern sports complex, and gas stations throughout the region.

Without any doubt, the Transnistrian industrial infrastructure has facilitated the substitution of the sovereign Moldovan government with the de facto state as the main actor engaged in the provision of local governance. The nature of local assets has enabled Transnistrian separatists to successfully construct a parallel system of governance. A 2004 International Crisis Group report noted that Transnistria "established and consolidated its own statelike structures: it has an elected president and parliament, a national bank that issues currency, a judicial system from the lowest courts up to a Constitutional Court, an army, police, militia, a strong internal security service, border guards and a customs service, a constitution, a national anthem, a coat of arms, and a flag" (International Crisis Group, 2004). Residents of breakaway statelet enjoy free health care, free education, subsidized gas and public transportation, and a flat tax rate of $10 \%$. Thus, the logic discussed above, coupled with the Somaliland and Transnistria examples, suggest that industrial or agricultural infrastructures comprising relatively immobile assets can positively impact separatists' efforts to establish governance institutions - especially extractive and redistributive institutions.

The presence of expropriable mineral resources, such as diamonds, gold, or other precious gemstones, can also affect separatists' incentives to invest in institutionalizing their rule. When they exert control over areas rich in mineral resources, insurgents have rational incentives to eschew productive activities and engage in predatory behavior (Beardsley and McQuinn, 2009; Haer et al., 2020). Environments rich in lootable resources disincentivize separatists from ruling extensively because access to material assets is not dependent on their governance strategy. Expropriable mineral endowments, such as alluvial diamonds or precious metals, can transform secessionist enclaves into rentier de facto states where revenue is generated from nonproductive activities and where local rulers derive greater utility from predation rather than institutionalized rule.

Mineral resource endowments tend to attract opportunistic insurgents who are likely to be undisciplined, violent, and exploitative of the local population (Weinstein, 2007). Rebels with access to lucrative mineral resources are maximizers of revenue than of social welfare. The main function of the institutions constructed by insurgents in resource-abundant environments is to lower the cost of operating a violence monopoly rather than to develop a complex apparatus of extraction, redistribution, and political organization. The presence of lootable mineral resources provides access to the material 
Table I. Theoretical expectations ( $\uparrow$ positive effect; $\downarrow$ negative effect; $\equiv$ ambiguous effect).

\begin{tabular}{lcccc}
\hline & $\begin{array}{c}\text { All governance } \\
\text { institutions }\end{array}$ & $\begin{array}{c}\text { Political } \\
\text { institutions }\end{array}$ & $\begin{array}{c}\text { Redistributive } \\
\text { institutions }\end{array}$ & $\begin{array}{c}\text { Regularized } \\
\text { taxation }\end{array}$ \\
\hline Military support & $\uparrow$ & $\uparrow$ & $\uparrow$ & $\equiv$ \\
Peacekeepers & $\uparrow$ & $\uparrow$ & $\uparrow$ & $\equiv$ \\
Fragmentation & $\downarrow$ & $\equiv$ & $\downarrow$ & $\downarrow$ \\
Immobile assets & $\uparrow$ & $\equiv$ & $\uparrow$ & $\uparrow$ \\
Mineral resources & $\downarrow$ & $\equiv$ & $\downarrow$ & $\downarrow$ \\
\hline
\end{tabular}

basis needed to overcome collective action problems and maintain mobilization against the government, and obviates the need for a social contract between the rebels and the population whereby the legitimacy of the former is linked to the provision of governance to the latter. By contrast, resource-scarce settings incentivize rebel groups to settle down, become "rulers of the domain," and forge a social contract with civilians (Olson, 1993). Where mineral resources are meager, rebels are more likely to build governance institutions in an attempt to legitimize their authority and secure regularized taxation. The lack of access to lootable resources may galvanize insurgent groups to organize "true counterstates" (Tilly, 1990; Wickham-Crowley, 1987: 487) with many trappings of statehood that allow them to monopolize activity in the area under their control and acquire the wherewithal necessary to survive and pursue their strategic objectives. Therefore, the expectation is that expropriable mineral resources would correlate negatively with the extent of governance in de facto states: all else equal, in resource-rich environments insurgents tend to be predatory while in resource-scarce milieus they tend to be stationary. ${ }^{5}$

While lootable mineral resources are expected to lower the likelihood of regularized extraction/taxation (pertaining to the broader economic activity in separatist-controlled territories) and redistribution/public goods provision, their impact on rebel political institutions looks more ambiguous. On the one hand, access to lucrative natural endowments encourages opportunism and could foster organizationally lean insurgencies. On the other hand, revenues accrued through the exploitation of mineral resources can help offset the costs of establishing and maintaining political institutions needed for the long-term viability of an insurgency, especially of one with a strong ideological profile. The data on the types of governance institutions built in de facto states is wellequipped to adjudicate between these possible scenarios. Table 1 provides an overview of the main expectations.

\section{Research design}

The theoretical expectations are tested using new data on the entire population of de facto states between 1945 and 2016 (Florea, 2014). A de facto state is an armed nonstate actor that: belongs to (or is administered by) a recognized country, but is not a colonial possession; seeks some degree of separation from that country and has declared independence (or has demonstrated aspirations for independence, for example through a referendum or a sovereignty declaration); exerts military control over a territory or portions of territory 
inhabited by a permanent population; is not condoned by the government; lacks international legal sovereignty; ${ }^{6}$ and exists for at least 24 months. This definition yields a population of 40 de facto states between 1945 and 2016 (Table 2) that experienced varying outcomes after their emergence: six were forcefully reintegrated into their parent states; another six were peacefully reincorporated with some degree of autonomy; four made the transition to statehood; and, 24 were alive at the end of the observation period (2016). ${ }^{7}$

\section{Dependent variable}

The dependent variable captures the number of governance institutions that a de facto state exhibits in any given year of its existence. Most armed nonstate actors are not unitary (Bakke et al., 2012) but encompass multiple factions that often fight with one another rather than against a common external enemy. The governance variable records the entire range of political, redistributive, and extractive institutions established by the hegemonic/dominant faction in each de facto state during each year of its survival period (or until December 2016 if a de facto state was still alive by then). Specifically, this variable is a count of the number of statelike institutions in each de facto state, and includes ten indicators of political, redistributive, and extractive institutions ${ }^{8}$ :

(1) an executive - coded as present if there is an executive authority that makes decisions in the de facto state (a self-proclaimed, appointed, or elected separatist leader who heads an executive branch that is at least minimally formalized through an executive office)

(2) a legislature and/or regional council — coded as present if there is a legislative body and/or regional council in the de facto state capital that enacts local laws ${ }^{9}$

(3) a court or semiformalized legal system - coded as present if there is a formal or semiformal juridical authority that adjudicates disputes between individuals or institutions in the de facto state

(4) a central banking system - coded as present if the authorities in the de facto state establish a central banking system that functions separately from the parent state's banking network or if they adopt and widely use a different currency

(5) institutions for foreign affairs - coded as present if the authorities in the de facto state conduct diplomacy ${ }^{10}$ by creating a foreign affairs bureaucracy, establishing missions abroad, and/or engaging in formal contacts with nongovernmental organizations (NGOs), intergovernmental organizations (IGOs), foreign governments, or other subnational entities ${ }^{11}$

(6) media or propaganda institutions - coded as present if the authorities in the de facto state establish media or propaganda outlets (TV, newspapers, radio, or, more recently, social media presence) ${ }^{12}$

(7) an educational system - coded as present if the de facto state authorities establish a system of education that functions in parallel with, or in lieu of, the one provided by the parent state

(8) a welfare system - coded as present if the de facto state authorities establish a system of welfare (provision of health care and/or pensions) that replaces or complements the one provided by the parent state 
Table 2. Population of de facto states (1945-2016).

\begin{tabular}{|c|c|c|c|c|}
\hline De facto state & Parent state & Emergence & Disappearance & Type of disappearance \\
\hline Katanga & Congo (DRC) & 1960 & 1963 & forceful reintegration \\
\hline Biafra & Nigeria & 1967 & 1970 & forceful reintegration \\
\hline Krajina & Croatia & 1991 & 1995 & forceful reintegration \\
\hline Chechnya & Russia & 1991 & 1999 & forceful reintegration \\
\hline Anjouan & Comoros & 1997 & 2008 & forceful reintegration \\
\hline Tamil Eelam & Sri Lanka & 1984 & 2009 & forceful reintegration \\
\hline Rwenzururu Kingdom & Uganda & 1963 & 1982 & peaceful reintegration \\
\hline Gagauzia & Moldova & 1991 & 1995 & peaceful reintegration \\
\hline Bougainville & Papua New Guinea & 1975 & 1997 & peaceful reintegration \\
\hline Eastern Slavonia & Croatia & 1995 & 1998 & peaceful reintegration \\
\hline Ajaria & Georgia & 1991 & 2004 & peaceful reintegration \\
\hline Aceh & Indonesia & 2001 & 2005 & peaceful reintegration \\
\hline Karen State & Burma/Myanmar & 1949 & - & alive \\
\hline Kachin State & Burma/Myanmar & 1961 & - & alive \\
\hline Taiwan $^{a}$ & China & $197 \mid$ & - & alive \\
\hline Mindanao & Philippines & 1973 & - & alive \\
\hline$T R N C^{b}$ & Cyprus & 1974 & - & alive \\
\hline Western Sahara & Morocco $^{c}$ & 1974 & - & alive \\
\hline Cabinda & Angola & 1975 & - & alive \\
\hline Casamance & Senegal & 1982 & - & alive \\
\hline Abkhazia & Georgia & 1991 & - & alive \\
\hline Kurdistan & Iraq & 1991 & - & alive \\
\hline Nagorno-Karabakh & Azerbaijan & 1991 & - & alive \\
\hline Puntland & Somalia & 1991 & - & alive \\
\hline Somaliland & Somalia & 1991 & - & alive \\
\hline South Ossetia & Georgia & 1991 & - & alive \\
\hline Transnistria & Moldova & 1991 & - & alive \\
\hline Republika Srpska & Bosnia & 1992 & - & alive \\
\hline Palestine & Israel $^{d}$ & 1995 & - & alive \\
\hline Gaza & Palestine ${ }^{e}$ & 2007 & - & alive \\
\hline Azawad & Mali & 2012 & - & alive \\
\hline Cyrenaica/East Libya & Libya & 2012 & - & alive \\
\hline Islamic State, ISIS & Syria $^{f}$ & 2013 & - & alive \\
\hline Rojavag & Syria & 2013 & - & alive \\
\hline Donetsk $^{h}$ & Ukraine & 2014 & - & alive \\
\hline Luhansk ${ }^{i}$ & Ukraine & 2014 & - & alive \\
\hline Eritrea & Ethiopia & 1964 & 1993 & statehood \\
\hline East Timor & Indonesia & 1975 & 2002 & statehood \\
\hline Kosovo ${ }^{j}$ & Serbia & 1998 & 2008 & statehood \\
\hline South Sudan & Sudan & 1956 & 2011 & statehood \\
\hline
\end{tabular}

${ }^{\mathrm{a}}$ Taiwan became a de facto state when China replaced it within the UN; ${ }^{\mathrm{b}}$ Turkish Republic of Northern Cyprus; ${ }^{\mathrm{C}}$ Administered by Morocco; ${ }^{\mathrm{d}}$ Under Israeli occupation; 'Under Hamas control; 'Parent state is determined by the location of ISIS capital, Raqqa; ${ }^{8}$ Also known as the Democratic Federation of Northern Syria (DFNS);

h'Donetsk People's Republic (DPR); 'Luhansk People's Republic (LPR); 'Not a UN member. 
Table 3. Descriptive statistics.

\begin{tabular}{lccccr}
\hline & Min. & Max. & Median & Mean & St. dev. \\
\hline All governance institutions & 1 & 10 & 7 & 6.43 & 3.18 \\
Political institutions & 1 & 6 & 4 & 3.95 & 1.69 \\
Redistributive institutions & 0 & 3 & 3 & 1.78 & 1.40 \\
Taxation & 0 & 1 & 1 & 0.68 & 0.46 \\
Military support & 0 & 5 & 3 & 2.77 & 1.41 \\
Peacekeepers & 0 & 1 & 0 & 0.26 & 0.44 \\
Fragmentation & 1 & 21 & 3 & 4.32 & 3.55 \\
Immobile assets & 0 & 1 & 0 & 0.45 & 0.49 \\
Mineral resources & 0 & 1 & 0 & 0.44 & 0.49 \\
Ongoing war & 0 & 1 & 0 & 0.42 & 0.49 \\
Age & 0.1 & 68 & 15 & 17.71 & 14.15 \\
Relative mil. cap. & 1 & 4 & 2 & 2.20 & 0.90 \\
Ideology & 0 & 1 & 0 & 0.12 & 0.32 \\
Population (log) & 4 & 10.1 & 7.3 & 7.13 & 1.50 \\
Recognition & 0 & 190 & 0 & 7.74 & 23.02 \\
\hline
\end{tabular}

(9) a police and/or gendarmerie system - coded as present if the authorities in the de facto state establish a system of domestic control (police and/or gendarmerie) that operates separately from the separatist army

(10) a civilian tax system - coded as present if there are institutions for regularized extraction of taxes from local civilians/businesses or from the diaspora.

The mean for the governance variable is 6.43 while the median is 7 (Table 3 presents descriptive statistics). For instance, Transnistria (Moldova) registers a value of 7 for its emergence year (1991) and a value of 10 for the 1992-2011 period. Gagauzia, a short-lived de facto state in the same country, registers a value of 2 on this variable for its entire survival period (1991-1995). The dependent variable is further disaggregated into types of governance institutions: political institutions, a count variable which includes institutions 1 through 6 (executive, legislature, courts, central bank, foreign affairs, media); redistributive institutions, a count variable that includes institutions 7 through 9 (education, welfare, police); and extractive institutional framework, a binary variable that captures whether a civilian tax system is implemented.

\section{Independent variables}

The first expectation postulated that foreign military assistance can markedly shape insurgents' governance strategies by reducing their threat perception. The ideal measure for external military support would be an estimated dollar amount of military assistance a de facto state gets from other countries. The covert nature of military interactions between de facto states and external patrons limits the availability of such data. To circumvent this problem, I resort to a second-best measurement. Specifically, I construct a proxy that captures how much external military assistance a de facto state gets in any given year from 
state sponsors (Byman et al., 2001; Carter, 2012; San-Akca, 2016). This variable is an index of five types of external military support, where each type of support is weighted equally: (1) weaponry and military hardware; (2) foreign military personnel; (3) foreign military advisors; (4) training for de facto state troops abroad; and (5) safe havens. The mean value for this variable is 2.77 while its median is 3 . For example, Tamil Eelam registers a score of 4 for the 1984-1988 period when the LTTE received substantial support from India, and a score of 1 after 1988 when New Delhi withdrew its military assistance. The second expectation posited that the presence of peacekeepers can also diminish separatists' threat perceptions and spur governance activities. The presence of peacekeepers is captured with a binary variable, with coding based on Fortna (2008). ${ }^{13}$

The third proposition anticipated that de facto state governance could also be driven by the degree of fragmentation within the separatist movement. To measure fragmentation within each de facto state, I look at the number of factions that make demands on behalf of the separatist movement (Bakke et al., 2012). The higher the number of factions, the higher the level of fragmentation of the rebel movement. A faction is an organization that claims to represent the local population and makes demands regarding the status of the enclave, such as: reintegration into the parent state; limited autonomy; broad autonomy; no change in status; independence; (re)union with another state; membership in a supranational entity. A faction can be a political party, military group, or civic organization that operates within or outside the de facto state. The fragmentation variable ranges from 1 to 21 with a mean of 4.32 and a median of 3. Ajaria, Gagauzia, and Rwenzururu Kingdom are the only de facto states with a single faction throughout their entire existence while Palestine displays the largest number of factions -21 at the end of the observation period.

The fourth expectation held that fixed or relatively immobile assets, such as an industrial or agricultural infrastructure, can incentivize separatists to construct a complex governance apparatus. In the presence of such assets, insurgents have rational incentives to settle down and embark on the onerous, but potentially rewarding, task of governing the area under their control. To gauge the impact of asset specificity on de facto state leaders' incentives for greater or lesser governance, I rely on a binary variable that takes a value of 1 if there is an industrial (like in Donetsk People's Republic, Ukraine) or agricultural (like in Somaliland) infrastructure that is controlled by the hegemonic separatist group. Finally, the last proposition expected that expropriable mineral resources would encourage opportunistic rebel behavior and would correlate negatively with governance activities. To account for the effect of mineral resources on the variability in statelike institutions across de facto states, I use a dichotomous indicator that marks the presence of lootable mineral resources (gold, diamonds, gems, and other precious metals) in these enclaves. Mineral resource data are compiled from Ross (2004), the U.S. Geological Survey, and the Rebel Contraband Dataset (Walsh et al., 2018).

\section{Control variables}

Several factors can be systematically correlated with a separatist group's decision to create governance institutions as well as with the five covariates of interest. Much of the rebel governance process is endogenous to civil warfare. Ongoing war can critically 
shape rebel strategies regarding the institutionalization of an alternative system of government (Mampilly, 2011). Protracted fighting against the government, or against internal competitors that challenge the hegemonic faction, diverts resources from governance to military mobilization and exacerbates the uncertainty about the evolution of the conflict. Hence, ongoing conflict will likely reduce separatists' ability or willingness to engage in extensive governance practices. This control variable marks the presence of military conflict between separatists in de facto states and the government, or between the hegemonic faction in the enclave and internal adversaries. Data on internal war are based on the UCDP/PRIO Armed Conflict Dataset (Pettersson and Eck, 2018) where the threshold for observing conflict is at least 25 battle-related deaths per year.

The age of a de facto state is also expected to affect separatists' ability to institutionalize an alternative system of rule. The intuition here is that older breakaway territories would have had more time than younger peers to establish governance institutions. Additionally, the strength of the rebel group relative to the parent state-a proxy for the nature of the threat environment in which actors operate-might substantially impact separatists' incentives to become predatory or stationary. As Beardsley et al. (2015: 506) suggest, governance provision could be a function of relative capability: stronger insurgent groups are better positioned to stay localized, successfully compete with parent states, and gain legitimacy through the provision of order and public services. Following this logic, I include an ordinal variable that captures the relative capability between the separatist army and the government, with information from the Nonstate Actor Dataset (Cunningham et al., 2009). ${ }^{14}$

A large body of research (Kalyvas, 2015; Mampilly, 2011; Stewart, 2018) suggests that, given their focus on mass mobilization and class-based contention, Marxist/communist insurgencies are more likely to establish elaborate institutions of self-rule. As Stewart (2018) notes, these groups often create "people's governments" and engage in extensive public service provision. The ideological and organizational profile of Marxist/communist rebellions also equips them to commit more credibly to good governance, which is likely to facilitate civilian cooperation and reduce resistance to nonstate rule. To account for the effects of ideology on separatist governance, I include a binary variable, ideology, which marks whether the hegemonic faction in each de facto state embraces Marxist/communist precepts. Further, rebel governance can also be influenced by the size of the local population. Larger populations enlarge the set of taxable assets and activities, but also increase demand for public goods provided by the rebels. To account for this potentially confounding factor, I include a variable (logged) that captures the population in each de facto state. Finally, I control for the number of states that recognize a de facto state during each year of its survival (recognition). International recognition can affect patterns of external military support as well as the establishment of certain governance structures, such as an institutional architecture for the conduct of foreign relations.

\section{Results and discussion}

The empirical analysis is performed over four sets of dependent variables: a count of all governance institutions (Table 4); a count of political institutions (Table 5); a count of 
Table 4. Covariate effects on all governance institutions in de facto states.

\begin{tabular}{|c|c|c|c|c|}
\hline Variable & $\begin{array}{c}\text { Model } \\
\text { I }\end{array}$ & $\begin{array}{c}\text { Model } \\
2\end{array}$ & $\begin{array}{c}\text { Model } \\
3\end{array}$ & $\begin{array}{c}\text { Model } \\
4\end{array}$ \\
\hline Military support & $0.539 * *(0.276)$ & $0.488^{*}(0.265)$ & $0.493 *(0.255)$ & $0.367(0.25 I)$ \\
\hline Peacekeepers & $2.389 * * * *(0.559)$ & 2.43 I*** $(0.597)$ & $2.304 * * *(0.665)$ & $2.589 * * *(0.744)$ \\
\hline Fragmentation & $0.021(0.066)$ & $0.016(0.062)$ & $0.013(0.062)$ & $-0.058(0.076)$ \\
\hline Immobile assets & $\mathrm{I} .039(0.795)$ & I.I 44 (0.777) & I.374** (0.67I) & $1.524 * *(0.687)$ \\
\hline Mineral resources & $-2.184 * * *(0.837)$ & $-2.026 * * *(0.837)$ & $-2.254 * * *(0.810)$ & $-2.367 * * *(0.696)$ \\
\hline Ongoing war & & $-0.490(0.638)$ & $-0.582(0.495)$ & $-0.612(0.484)$ \\
\hline Age & & $0.043^{* * *}(0.013)$ & $0.057 * * *(0.016)$ & $0.055^{* * * *}(0.019)$ \\
\hline Relative mil. cap. & & & $0.545(0.493)$ & $0.576(0.439)$ \\
\hline Ideology & & & $2.174 * * *(0.785)$ & $2.246 * * *(0.802)$ \\
\hline Population (log) & & & & $0.242(0.293)$ \\
\hline Recognition & & & & $0.016(0.014)$ \\
\hline Constant & $4.7 I I$ I** $(0.62 I)$ & $4.18 I^{* * *}(0.859)$ & $2.54 I * * *(1.009)$ & $1.217(1.963)$ \\
\hline$N$ & 893 & 893 & 893 & 889 \\
\hline Nb. of groups & 40 & 40 & 40 & 40 \\
\hline
\end{tabular}

Interval regression coefficients are reported with robust standard errors clustered by de facto state (in parentheses).

The dependent variable is number of governance institutions in de facto states.

All covariates, except for age, are lagged one year to maintain their exogeneity vis-à-vis the outcome. $*_{p}<.10 ; * p<.05 ; * * * p<.01$.

redistributive institutions (Table 6); the presence of a regularized system of taxation/ extraction (Table 7). Given the nature of the dependent variables, ${ }^{15}$ auto-correlation, and nonindependence of observations (the establishment of governance institutions at time $t+1$ is unlikely to be independent of governance institutions at time $t$ ), I employ interval regression with robust standard errors clustered by de facto state to assess how the covariates impact the variability in different types of governance institutions (for the binary taxation outcome, I rely on logistic regression).$^{16}$ Interval regression is suitable for modeling outcomes with interval censoring where there is uncertainty about the true value of the dependent variable (Rabinowitz et al., 1995). To guard against false-positives, the coding protocol required at least three sources for marking the presence of each governance institution in every de facto state during each year of its survival period. ${ }^{17}$ Yet, as is the case with data collection that relies extensively on publicly available secondary sources (Huang, 2016a; Weidmann, 2016), completely eliminating false-positives (governance institutions may erroneously be reported to be present) or false-negatives (existing governance institutions may not be accurately reported) is a daunting task. Interval regression helps address this quandary by calculating the corresponding probability of the outcome value lying within the designated range. ${ }^{18}$

Tables 4 through 7 present the empirical results while Figure 1 depicts covariate effects on the predicted number of governance institutions. All variables (except for the age of a de facto state) are lagged one year to preserve their exogeneity vis-à-vis the 
Table 5. Covariate effects on political institutions in de facto states.

\begin{tabular}{|c|c|c|c|c|}
\hline Variable & Model 5 & Model 6 & Model 7 & Model 8 \\
\hline Military support & $0.435^{* * * *}(0.15 \mathrm{I})$ & $0.4 I 7^{* * *}(0.14 I)$ & $0.414 * * * *(0.135)$ & $0.359 * *(0.145)$ \\
\hline Peacekeepers & I.157**** $(0.28 I)$ & $1.102^{* * *}(0.298)$ & $1.009 * * * *(0.336)$ & $1.136 * * *(0.404)$ \\
\hline Fragmentation & $0.039(0.026)$ & $0.045(0.027)$ & $0.048(0.03 \mathrm{I})$ & $0.014(0.033)$ \\
\hline Immobile assets & $0.807 * *(0.410)$ & $0.795 * *(0.384)$ & $0.836 * *(0.363)$ & $0.903 * *(0.403)$ \\
\hline Mineral resources & $-0.843 * *(0.429)$ & $-0.755^{*}(0.453)$ & $-0.817^{* *}(0.416)$ & $-0.864^{* *}(0.375)$ \\
\hline Ongoing war & & $-0.374(0.309)$ & $-0.374(0.246)$ & $-0.379 *(0.223)$ \\
\hline Age & & $0.015^{* *}(0.006)$ & $0.021^{* * * *}(0.007)$ & $0.025 * *(0.008)$ \\
\hline Relative mil. cap. & & & $0.306(0.262)$ & $0.321(0.237)$ \\
\hline Ideology & & & $0.753^{* *}(0.34 I)$ & $0.785 * *(0.340)$ \\
\hline Population (log) & & & & $0.103(0.153)$ \\
\hline Recognition & & & & $0.007(0.006)$ \\
\hline Constant & $2.269 * * *(0.384)$ & $2.167 * * *(0.477)$ & $1.320 * *(0.561)$ & $0.748(1.054)$ \\
\hline$N$ & 893 & 893 & 893 & 889 \\
\hline$N b$. of groups & 40 & 40 & 40 & 40 \\
\hline
\end{tabular}

Interval regression coefficients are reported with robust standard errors clustered by de facto state (in parentheses).

The dependent variable is the number of political institutions in de facto states.

All covariates, except for age, are lagged one year to maintain their exogeneity vis-à-vis the outcome. $* p<.10 ; * * p .05 ; * * p<.01$.

Table 6. Covariate effects on redistributive institutions in de facto states.

\begin{tabular}{lrrrr}
\hline Variable & \multicolumn{1}{c}{ Model 9 } & \multicolumn{1}{c}{ Model I0 } & \multicolumn{1}{c}{ Model II } & \multicolumn{1}{c}{ Model I2 } \\
\hline Military support & $0.144(0.136)$ & $0.123(0.137)$ & $0.127(0.132)$ & $0.073(0.128)$ \\
Peacekeepers & $0.983^{* * *}(0.262)$ & $1.015^{* * *}(0.268)$ & $0.969^{* * *}(0.301)$ & $1.05 I^{* * *}(0.272)$ \\
Fragmentation & $0.022(0.034)$ & $0.019(0.032)$ & $0.016(0.030)$ & $-0.015(0.038)$ \\
Immobile assets & $0.064(0.373)$ & $0.118(0.379)$ & $0.252(0.305)$ & $0.345(0.306)$ \\
Mineral resources & $-0.98 I^{* * *}(0.370)$ & $-0.920^{* *}(0.388)$ & $-1.045^{* * *}(0.348)$ & $-1.099^{* * *}(0.298)$ \\
Ongoing war & & $-0.165(0.335)$ & $-0.225(0.277)$ & $-0.224(0.287)$ \\
Age & & $0.018^{* *}(0.008)$ & $0.024^{* *}(0.010)$ & $0.024^{* *}(0.010)$ \\
Relative mil. cap. & & & $0.236(0.193)$ & $0.253(0.176)$ \\
Ideology & & & $1.123^{* * *}(0.429)$ & $1.158^{* * *}(0.438)$ \\
Population (log) & & & & $0.084(0.108)$ \\
Recognition & & & & $0.008(0.007)$ \\
Constant & $1.426 * * *(0.278)$ & $1.185^{* * *}(0.386)$ & $0.446(0.472)$ & $-0.014(0.816)$ \\
$N$ & 893 & 893 & 893 & 889 \\
$N b$ of groups & 40 & 40 & 40 & 40 \\
\hline
\end{tabular}

Interval regression coefficients are reported with robust standard errors clustered by de facto state (in parentheses).

The dependent variable is number of redistributive institutions in de facto states.

All covariates, except for age, are lagged one year to maintain their exogeneity vis-à-vis the outcome. $* p<.10 ; * * p<.05 ; * * * p<.01$. 
Table 7. Covariate effects on the presence of regularized taxation in de facto states.

\begin{tabular}{|c|c|c|c|c|}
\hline Variable & Model 13 & Model I4 & Model I5 & Model 16 \\
\hline Military support & $-0.040(0.181)$ & $-0.116(0.204)$ & $-0.027(0.229)$ & $-0.080(0.254)$ \\
\hline Peacekeepers & $1.794 * * *(0.555)$ & $2.33 \mathrm{I} * * *(0.604)$ & $2.71 \mathrm{I} * * *(0.636)$ & $2.95 \mathrm{I} * * *(0.583)$ \\
\hline Fragmentation & $-0.207 * *(0.087)$ & $-0.255^{* * *}(0.087)$ & $-0.299 * * *(0.085)$ & $-0.340 * * *(0.119)$ \\
\hline Immobile assets & I.I74* (0.700) & I.578** (0.758) & $2.326 * * *(0.849)$ & $2.224 * * *(0.830)$ \\
\hline Mineral resources & $-2.116 * * *(0.693)$ & $-2.227 * * *(0.808)$ & $-2.856 * * *(0.837)$ & $-3.015^{* * *}(0.922)$ \\
\hline Ongoing war & & $0.498(0.540)$ & $0.346(0.535)$ & $0.011(0.517)$ \\
\hline Age & & $0.067 * * *(0.020)$ & $0.083 * * *(0.018)$ & $0.074 * * *(0.022)$ \\
\hline Relative mil. cap. & & & $0.393(0.507)$ & $0.232(0.477)$ \\
\hline Ideology & & & $2.139 * *(0.949)$ & $2.238 * *(0.968)$ \\
\hline Population (log) & & & & $0.375(0.290)$ \\
\hline Recognition & & & & $0.002(0.017)$ \\
\hline Constant & $2.116^{* * *}(0.797)$ & $0.966(0.931)$ & $-0.435(1.239)$ & $-2.126(I .747)$ \\
\hline$N$ & 893 & 893 & 893 & 889 \\
\hline Nb. of groups & 40 & 40 & 40 & 40 \\
\hline
\end{tabular}

Logit coefficients are reported with robust standard errors clustered by de facto state (in parentheses).

The dependent variable is presence of regularized taxation in de facto states.

All covariates, except for age, are lagged one year to maintain their exogeneity vis-à-vis the outcome. $*_{p}<.10 ; * *_{p}<.05 ; * * *_{p}<.01$.

outcome. Overall, the findings are mixed and reveal intriguing variability in the relationship between the main variables and outcomes. Contrary to expectations, external military support does not seem to have a significant effect on the overall number of governance institutions (Model 4). Once we disaggregate the governance variable, however, the picture is more nuanced: while military support remains insignificant for redistributive (Model 12) and extractive (Model 16) institutions, it displays a positive and significant effect for political institutions (Model 8). Specifically, for each type of external military support received by de facto states, the average number of political institutions increases by 0.359 (Model 8 estimates). Military assistance from third party sponsors seems to reduce the uncertainty about maintaining mobilization against the government and facilitates the allocation of a greater share of resources to the development of political institutions. Under the protection of external backers, de facto states appear to be better equipped to establish themselves as strong political contenders and challenge institutionally the authority of parent states.

As expected, the presence of peacekeepers is positively associated with state-building activities. A de facto state that has peacekeepers on its territory manages to build, on average, 2.589 additional governance institutions compared to a separatist enclave where peacekeepers are absent (Model 4). The positive impact of peacekeepers on de facto state governance remains strong and statistically significant even when governance institutions are functionally disaggregated (Models 8,12 , and 16). These large and highly significant effects support the idea that, by preventing the resumption of hostilities and freezing the status quo, peacekeeping operations can considerably alter the threat environment in which separatists operate and can inadvertently facilitate the consolidation of nonstate actor rule. The results suggest that, at least for a subset of separatist struggles, peacekeeping operations may be 


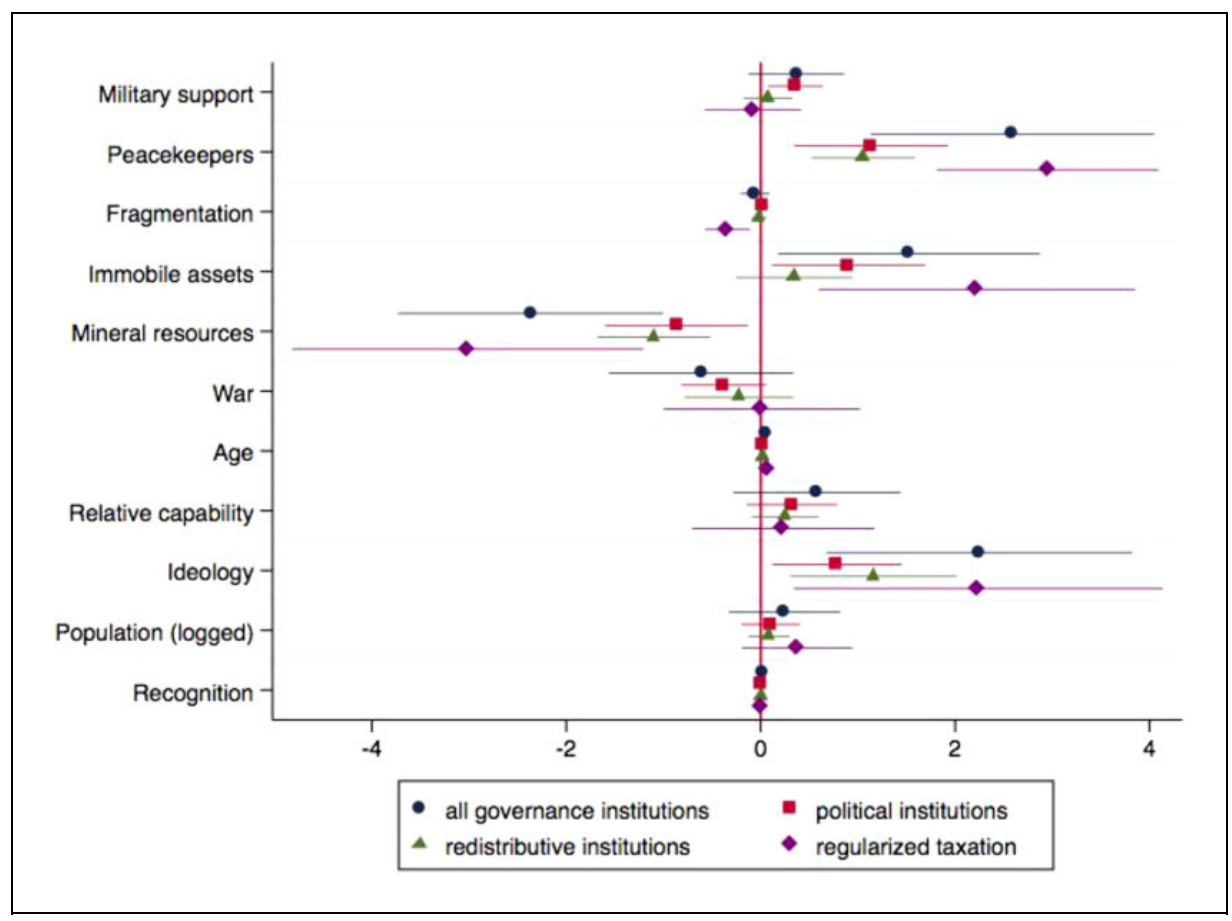

Figure I. Covariate marginal effects on the types of governance institutions in de facto states.

more useful as conflict prevention tools than as conflict resolution mechanisms. The institutionalization of rebel rule in separatist enclaves where peacekeepers are present likely reduces insurgents' incentives to agree to any deal that marks a departure from the status quo - a situation which is likely to prolong, rather than solve, the conflict.

When we look at the results for all governance institutions (Model 4) the sign for fragmentation operates in the expected negative direction but fails to reach statistical significance. Might it be that internecine rivalry within de facto states impacts certain kinds of governance institutions rather than others? The findings seem to support this suspicion. While fragmentation does not appear to affect de facto state leaders' ability to build political and redistributive institutions (Models 8 and 12), it displays a strong, statistically significant, negative effect on rebel extraction. Model 12 in Table 7 provides solid evidence that fragmentation severely undermines separatists' efforts to engage in regularized taxation. This could be due to the fact that groups engaged in competition with internal rivals may lack the resources necessary to extract from the local population or to the fact that, faced with attempts at taxation from multiple rebel factions, local communities are able to mobilize more effectively and mount a successful resistance against rebel rule (Kaplan, 2017). Further inquiries are necessary to shed better light on the processes that link rebel fragmentation with rebel taxation in de facto states and beyond.

Tables 4 through 7 indicate varying effects of resource endowments on the types of governance institutions built by de facto state leaders. Relatively fixed or immobile 
assets show a positive and statistically significant impact on all governance institutions (Model 4), but more prominently on political and extractive institutions (Models 8 and 16). The nature of economic assets in de facto states seems to exert a substantial influence on separatists' ability to expand the range of political institutions and to implement effective taxation practices. Contrary to expectations, the results indicate that rebel control over relatively immobile assets does not necessarily encourage redistribution/public goods provision. This suggests that the revenues accrued through productive economic activities tend to be channelled towards the distribution of club, rather than public, goods.

The expectation that lootable mineral resources would correlate negatively with separatist governance is strongly supported. Across models with both the aggregated (Model 4) and disaggregated dependent variable (Models 8, 12, and 16), the sign for this covariate operates in the expected negative direction and conveys that the presence of expropriable mineral resources reduces separatists' incentives to build statelike institutions. All else equal, those de facto states with lootable mineral resources display, on average, 2.367 fewer governance institutions compared to those that don't have such resources. These patterns lend additional support to the conjecture that, in resource-rich environments, insurgents are less incentivized to invest in institutionalizing their rule (Weinstein, 2007).

As for the control variables, a few trends are noteworthy. Ongoing war operates in the expected direction but fails to reach conventional standards of statistical significance. ${ }^{19}$ This finding is not entirely surprising since, after separating from their parent states, many de facto states have experienced low levels of violence with limited potential to completely disrupt governance processes. The military balance of power between parent states and separatists after the latter's de facto separation coupled, in many cases, with the presence of peacekepeers function as strong deterrents against the resumption of violence. Under these conditions, de factor state leaders are able continue their state building process unencumbered.

As anticipated, the age of a de facto state positively affects observed levels of governance. This result is intuitive: the older a de facto state is, the more time it would have had to establish governance institutions. Prolonged de facto separation allows separatists to solidify their rule and overcome the collective action problems inherent in the statebuilding process. The sign for relative military capability operates in the expected direction - stronger rebels would be expected to provide governance more extensively than weaker rebels - but fails to achieve significance. Notably, this variable remains insignificant even when external military support is dropped from the model due to collinearity concerns. ${ }^{20}$ On the other hand, ideology emerges as strong predictor of the extent of rebel governance across de facto states: all else equal, separatist enclaves ruled by an organization that adopts a Marxist/communist agenda display, on average, 2.246 additional governance institutions compared to those de facto states controlled by differently motivated groups. When we disaggregate governance institutions, we notice that, expectedly, ideology's strongest impact is on redistributive and extractive institutions (Models 12 and 16) rather than political institutions (Model 8). These findings corroborate existing studies (Mampilly, 2011; Stewart, 2018) which argue that one of the hallmarks of Marxist/communist insurgencies is revolutionary state building-the 
construction of an apparatus of self-rule as an alternative authority structure to a predatory central government. Finally, neither population nor recognition achieves significance. The result for the population variable validates the observed distribution of governance institutions across both larger and smaller de facto states. For example, a comparatively high number of governance institutions can be seen both in South Ossetia (Georgia), with a population of approximately 50,000 people, and in Somaliland (Somalia), with a population of roughly 3.5 million people. The trend for international recognition (captured by the number of UN member states that recognize a de facto state during each year of its existence) is not surprising either: international recognition is quite rare among de facto states (see Table 3) while governance activities are fairly common (hence, other factors must be driving the variation in outcome).

\section{Conclusion}

De facto states, such as Abkhazia or Northern Cyprus, are resilient separatist enclaves that strive to achieve independence. To bolster their domestic and international legitimacy, these entities embark on wide range of governance activities and appropriate most, if not all, functions of sovereign statehood. Despite the fact that successful state-building efforts enhance de facto states' legitimacy with domestic and international audiences and strengthen their independence claims, these armed nonstate actors engage in varying governance practices: some construct a fully functional statelike apparatus of separate rule while others are less successful at governing the territory and population under their control.

Relying on originally collected data for all de facto states between 1945 and 2016, this study argued that the variation in governance processes observed across these nonstate actors is driven by the nature of the threat environment in which they operate, the organizational structure of the movement, and the type of resource endowments present in the breakaway enclaves. In particular, five key factors related to the nature of the threat environment, rebel organizational structure, and resource endowments were posited to affect not just the presence but, more importantly, the types of governance institutions (political institutions; redistributive institutions; extractive institutions) established by de facto state leaders: external military support; peacekeepers; fragmentation within the separatist movement; the nature of local assets; and the availability of mineral resources.

Several empirical patterns stand out. External military support from third-party sponsors was found to only enhance separatists' political footprint rather than the broader palette of extractive and redistributive activities. By contrast, results revealed that the presence of international peacekeepers reduces threat perceptions and positively affects the whole range of governance institutions (political, redistributive, extractive). The organizational structure of the separatist movement (whether it is unitary or fragmented) does not appear to affect de facto state leaders' ability to build political and redistributive institutions but has a strong, negative effect on extraction/taxation: the more internally split the separatist movement is, the lower the likelihood of observing regularized taxation in breakaway territories. As for the effect of resource endowments, the presence of relatively fixed or immobile assets displays a positive impact on all types of governance institutions but especially on political and extractive institutions. Access to expropriable mineral resources was found to strongly reduce incentives to build 
statelike institutions across the board. Finally, the analysis revealed that state-building is likely to be more extensive when separatists embrace a Marxist/communist ideology and when the enclave has survived for a long period of time.

The findings carry several implications. Thus far, the bulk of the literature on rebel governance has examined the influence of insurgents' state-building activities on various conflict outcomes, such as negotiations (Heger and Jung, 2017), civilian resistance against rebel rule (Arjona, 2016), or post-conflict democratization (Huang, 2016a). With a few exceptions (Arjona, 2016; Mampilly, 2011; Stewart, 2018), the factors that explain the variation in rebel governance itself have not been thoroughly investigated. This article expands our knowledge of the conditions under which rebels are most likely to establish complex institutions of self-rule. The study's key contribution is to explain not only whether armed nonstate actors engage in governance but, more importantly, what kind of governance institutions they are more inclined to build and why.

More broadly, this article contributes to ongoing debates about state-building processes in the midst of civil warfare. De facto states are territories where two rival sovereigns, a legally sovereign government and an empirically sovereign rebel movement, compete for power and engage in a gamut of governance activities, setting up political, extractive, and redistributive institutions that showcase their ability to rule effectively. The patterns gleaned from the empirical analysis enhance our understanding of authority fragmentation between state and nonstate territorial actors in the contemporary international system (Staniland, 2012). Large swaths of land across Eurasia, North Africa, or the Middle East remain under the control of rebel organizations that consolidate their rule through the establishment of sophisticated governance systems. Although in the public discourse these areas are typically described as being "ungoverned," they are, in fact, "differently governed" (Clunan and Trinkunas, 2010; Risse, 2011). Where state authority is displaced following violent rebellions, internal anarchy does not automatically ensue; rather, in many civil war situations, nonstate territorial actors consolidate alternative structures of authority and, thus, pose a serious challenge to territorial statehood and sovereignty (Lemke and Crabtree, 2020). In the contemporary international environment, the Weberian state no longer holds a monopoly over the governance market (if it ever did). Instead, the state is joined by a plethora of "other actors, benign and malign, who sometimes compete... in providing governance and security" (Clunan and Trinkunas, 2010: 6).

This study holds policy relevance as well. The international community is presented with two antithetical images of rebel governance: a "malign" rebel governance image whereby radical insurgencies, such as the one carried out by the Islamic State of Iraq and al-Sham (ISIS) in Syria and Iraq, secure territorial control, operate economies of warfare, engage in clandestine activities, forge bonds with the local population, attract ideologically committed recruits, and create a cauldron of instability across large pockets of territory; and, a "benign" rebel governance image whereby moderate rebellions, such as the one in Iraqi Kurdistan, successfully manage local affairs and provide order and security in what might otherwise be an anarchic environment. Devising the best policy instruments to deal with these contemporary challenges requires a deep appreciation of the incentives rebels have to become "rulers of their own domains." This study aspired to take us closer to a better understanding of those incentives. 


\section{Acknowledgments}

I thank Kristin Bakke, Karlo Basta, Nina Caspersen, Erica Chenoweth, Bridget Coggins, Kathleen Cunningham, Ryan Griffiths, Reyko Huang, George Kyris, Cyanne Loyle, Zachariah Mampilly, Theodore McLauchlin, Scott Pegg, Jessica Steinberg, and Megan Stewart for their feedback on earlier versions. I am also grateful to the EJIR editors and the anonymous reviewers for their detailed comments. Anna Kabedeva and Stephen Powell provided excellent research assistance.

\section{Funding}

The author disclosed receipt of the following financial support for the research, authorship, and/or publication of this article: Support from the British Academy (SG171035) and the Carnegie Trust for the Universities of Scotland (70580) for the collection of data on the post-2011 de facto states is gratefully acknowledged.

\section{ORCID iD}

Adrian Florea (D) https://orcid.org/0000-0002-7493-9307

\section{Supplemental material}

Supplemental material for this article is available online.

\section{Notes}

1. Rebels, insurgents, and armed nonstate actors are used interchangeably to describe armed nonstate organizations that employ violent or nonviolent tactics in pursuit of political objectives, such as secession or government overthrow. Rebel governance, rebel government, and rebel state-building are also used interchangeably to describe institutionalized governance practices conducted by armed nonstate organizations.

2. Such support may disincentivize separatists to engage in regularized extraction. Beardsley and Quinn (2009) argue that the availability of external resources reduces incentives for local governance: assistance from third parties creates opportunistic rebels who are interested in short-term private gains rather than in long-term benefits accrued through the establishment of a governance apparatus.

3. This is because pure coercion encourages underproduction. As Olson (1993: 568) put it, "in a world of roving banditry, there is little or no incentive for anyone to produce or accumulate anything that may be stolen and, thus, little for bandits to steal."

4. Paradoxically, the Moldovan government purchases electricity from the separatists in Transnistria.

5. I exclude oil from the range of expropriable mineral resources for two reasons. First, few de facto states posess(ed) substantial oil reserves on their territory (some exceptions are Aceh, Biafra, Chechnya, Kurdistan, and South Sudan). Second, oil is not an easily lootable asset as it requires an infrastructure for production and transport. By contrast, although mining sites for precious minerals are relatively fixed, their output is much more mobile than oil and, thus, easier to expropriate.

6. International legal sovereignty refers to recognition from a simple majority of United Nations Security Council (UNSC) permanent members plus recognition from a simple majority of UN members. 
7. The supplementary materials include details about data collection and the codebook for the de facto state dataset.

8. Reports on the simple presence of a governance institution were not sufficient for coding purposes; rather, the coding process involved looking for information that the respective institution was functional. For example, in the early 1990s, separatists from Republika Srpska Krajina, a Serbian enclave in Croatia, established a "Ministry of Foreign Affairs." However, this institution existed primarily on paper; in practice, this "Ministry" did not have a proper office or even diplomats who could speak a foreign language (Caspersen, 2012). In this case, the coding did not record a functional institution for the conduct of foreign affairs.

9. Where they are present, "rubber-stamp" legislatures in de facto states perform similar functions as parliaments in dictatorships. Separatist leaders typically establish these official, yet powerless, bodies to project at least a modicum of legitimacy but, most importantly, to neutralize internal threats to their power.

10. According to Huang (2016b: 94), a rebel group conducts diplomacy when it engages in any of the following acts: (1) opens a political office abroad; (2) sends representatives abroad on political missions; or (3) creates a political body devoted to the conduct of foreign affairs.

11. Coggins (2015: 115) makes a compelling case that rebel diplomacy is an instance of rebel governance as it can affect insurgents' ability to consolidate their rule and provide public goods. Huang (2016b: 100-101) holds that diplomacy is a form of "rebelcraft" which allows rebel groups to showcase that they "are capable of conducting an important act-foreign affairs - that is typically understood to be the preserve of recognized states."

12. The establishment of a media system by armed nonstate actors is a manifestly political decision. Some de facto states, like Iraqi Kurdistan or Nagorno-Karabakh, have recently established a strong social media presence, especially on Twitter.

13. Original coding was carried out for the years not covered by Fortna (2008) following a similar protocol.

14. This variable includes the following categories: 1 weaker than the government; 2 at parity with the government; 3 stronger than the government; 4 much stronger than the government. Original coding was carried out for the years not covered in the Nonstate Actor Dataset following a similar protocol.

15. By construction, a de facto state can display between 0 and 10 total governance institutions, between 0 and 6 political institutions, and between 0 and 3 redistributive institutions.

16. Alternative estimators (OLS and Tobit) produce substantively similar results. I provide several robustness tests in the supplemental materials.

17. Coding decisions were taken very conservatively - each governance institution required at least three independent sources to be coded as present. Coding procedures are discussed in the supplementary materials.

18. 0 to 10 for overall number of governance institutions, 0 to 6 for political institutions, 0 to 3 for redistributive institutions.

19. An exception is the negative impact of warfare on political institutions. As this finding is significant only at .10 level, it needs to be taken with caution.

20. See the robustness tests in the supplemental materials.

\section{References}

Ahram A (2019) Break All Borders: Separatism and the Reshaping of the Middle East. New York: Oxford University Press.

Akcinaroglu S and Tokdemir E (2018) To instill fear and love: terrorist groups and the strategy of building reputation. Conflict Management and Peace Science 35(4): 355-377. 
Arjona A (2016) Rebelocracy: Social Order in the Colombian Civil War. New York: Cambridge University Press.

Arjona A, Kasfir N and Mampilly Z (eds) (2015) Rebel Governance in Civil War. New York: Cambridge University Press.

Bakke KM, Cunningham KG and Seymour L (2012) A plague of initials: fragmentation, cohesion, and infighting in civil wars. Perspectives on Politics 10(2): 265-284.

Beardsley K, Gleditsch KS and Lo N (2015) Roving bandits? The geographical evolution of African armed conflicts. International Studies Quarterly 59(3): 503-516.

Beardsley K and Gleditsch KS (2015) Peacekeeping as conflict containment. International Studies Review 17(1): 67-89.

Beardsley K and McQuinn B (2009) Rebel groups as predatory organizations. Journal of Conflict Resolution 53(4): 624-645.

Berg E and Van Houtum H (eds) (2003) Routing Borders Between Territories, Discourses, and Practices. Malden: Ashgate.

Berti B (2015) Non-state actors as providers of governance: the Hamas government in Gaza between effective sovereignty, centralized authority, and resistance. Middle East Journal 69(1): 9-31.

Blakkisrud $\mathrm{H}$ and Kolsto P (2011) From secessionist conflict toward a functioning state: processes of state- and nation-building in Transnistria. Post-Soviet Affairs 27(2): 178-210.

Byman DL (2005) Deadly Connections: States That Sponsor Terrorism. New York: Cambridge University Press.

Byman DL, Chalk P, Hoffman B, et al. (2001) Trends in Outside Support for Insurgent Movements. Santa Monica: RAND Corporation.

Calus K (2013) An Aided Economy: The Characteristics of the Transnistrian Economic Model. Warsaw: Centre for Eastern Studies. Available at: http://www.osw.waw.pl/en/publikacje/ osw-commentary/2013-05-16/aided-economy-characteristics-transnistrian-economic-model (accessed 25 October 2017).

Carter DB (2012) A blessing or a curse? State support for terrorist groups. International Organization 66(1): 129-151.

Caspersen N (2012) Unrecognized States: The Struggle for Sovereignty in the Modern International System. Malden: Polity Press.

Clunan AL and Trinkunas HA (eds) (2010) Ungoverned Spaces: Alternatives to State Authority in an Era of Softened Sovereignty. Stanford: Stanford University Press.

Coggins B (2014) Power Politics and State Formation in the Twentieth Century: The Dynamics of Recognition. New York: Cambridge University Press.

Coggins B (2015) Rebel diplomacy: theorizing violent non-state actors' strategic use of talk. In: Arjona A, Kasfir N and Mampilly Z (eds) Rebel Governance in Civil War. New York: Cambridge University Press, 98-118.

Cunningham KG (2015) Inside the Politics of Self-Determination. New York: Oxford University Press.

Cunningham DE, Gleditsch KS and Salehyan I (2009) It takes two: a dyadic analysis of civil war duration and outcome. Journal of Conflict Resolution 53(4): 570-597.

de la Sierra RS (2020) On the origin of states: stationary bandits and taxation in Eastern Congo. Journal of Political Economy 128(1): 32-74.

Florea A (2014) De facto states in international politics (1945-2011): a new dataset. International Interactions 40(5): 788-811.

Florea A (2017) De facto states: survival and disappearance (1945-2011). International Studies Quarterly 61(2): 337-351. 
Fortna VP (2008) Does Peacekeeping Work? Shaping Belligerents' Choices After Civil War. Princeton: Princeton University Press.

Griffiths R (2016) Age of Secession: The International and Domestic Determinants of State Birth. New York: Cambridge University Press.

Haer R, Faulkner CM and Whitaker BE (2020) Rebel funding and child soldiers: exploring the relationship between natural resources and forcible recruitment. European Journal of International Relations 26(1): 236-262.

Hashim AS (2013) When Counterinsurgency Wins: Sri Lanka's Defeat of the Tamil Tigers. Philadelphia: University of Pennsylvania Press.

Heger LL and Jung DF (2017) Negotiating with rebels: the effect of rebel service provision on conflict negotiations. Journal of Conflict Resolution 61(6): 1203-1229.

Hill WH (2012) Russia, The Near Abroad, and the West: Lessons from the MoldovaTransdniestria Conflict. Baltimore, MD: Johns Hopkins University Press.

Huang R (2016a) The Wartime Origins of Democratization: Civil War, Rebel Governance, and Political Regimes. New York: Cambridge University Press.

Huang R (2016b) Rebel diplomacy in civil war. International Security 40(4): 89-126.

International Crisis Group (ICG) (2004) Europe Report No. 157. Moldova: Regional tensions over Transdniestria. Available at: http://www.crisisgroup.org/media/Files/europe/157।_moldoval_ regional _tensions $\_\_$over $\_$transdniestria.pdf\} (accessed 24 February 2018).

Kalyvas S (2006) The Logic of Violence in Civil Wars. New York: Cambridge University Press.

Kalyvas S (2015) Rebel governance during the Greek civil war, 1942-1949. In: Arjona A, Kasfir N and Mampilly Z (eds) Rebel Governance in Civil War. New York: Cambridge University Press, $119-137$.

Kaplan O (2017) Resisting War: How Communities Protect Themselves. New York: Cambridge University Press.

Keating J (2018) Invisible Countries: Journeys to the Edge of Nationhood. New Haven: Yale University Press.

Ker-Lindsay J (2012) The Foreign Policy of Counter-Secession: Preventing the Recognition of Contested States. New York: Cambridge University Press.

Lemke D and Crabtree C (2020) Territorial contenders in world politics. Journal of Conflict Resolution 64(2-3): 518-544.

Lynch D (2004) Engaging Eurasia's Separatist States: Unresolved Conflicts and De Facto States. Washington, DC: USIP Press.

Mampilly Z (2011) Rebel Rulers: Insurgent Governance and Civilian Life During War. Ithaca, NY: Cornell University Press.

Metelits C (2010) Inside Insurgency: Violence, Civilians, and Revolutionary Group Behavior. New York: NYU Press.

Muhumed MM and Yonis AM (2018) The future of Somaliland livestock exports: examining the sustainability of livestock trade. International Journal of Management, Accounting and Economics 5(8): 678-692.

Nalla M (2010) Crime and Punishment Around the World. Santa Barbara: ABC-CLIO.

Natali D (2010) The Kurdish Quasi-State. Syracuse: Syracuse University Press.

Olson M (1993) Dictatorship, democracy, and development. American Political Science Review 87(3): $567-576$.

Pearlman W (2011) Violence, Nonviolence, and the Palestinian National Movement. New York: Cambridge University Press.

Pegg S (1998) International Society and the De Facto State. Aldershot, MA: Ashgate.

Pettersson T and Eck K (2018) Organized violence, 1989-2017. Journal of Peace Research 55(4): 535-547. 
Podder S (2014) Mainstreaming the non-state in bottom-up state-building: linkages between rebel governance and post-conflict legitimacy. Conflict, Security \& Development 14(2): 213-243.

Rabinowitz D, Tsiatis A and Aragon J (1995) Regression with interval-censored data. Biometrika 82(3): 501-513.

Reno W (2011) Warfare in Independent Africa: New Approaches to African History. New York: Cambridge University Press.

Revkin MR (2020) What explains taxation by resource-rich rebels? Evidence from the Islamic State in Syria. Forthcoming in the Journal of Politics. Available at: https://www.journals.u chicago.edu/doi/abs/10.1086/706597?journalCode=jop

Risse T (ed.) (2011) Governance Without a State: Policies an Politics in Areas of Limited Statehood. New York: Columbia University Press.

Ross ML (2004) What do we know about natural resources and civil war? Journal of Peace Research 41(3): 337-356.

Sabates-Wheeler R and Verwimp P (2014) Extortion with protection: understanding the effect of rebel taxation on civilian welfare in Burundi. Journal of Conflict Resolution 58(8): 1474-1499.

San-Akca B (2016) States in Disguise: Causes of State Support for Rebel Groups. New York: Oxford University Press.

Seymour L, Bakke KM and Cunningham KG (2016) 'E pluribus unum, ex uno plures:' competition, violence, and fragmentation in ethnopolitical movements. Journal of Peace Research 53(1): 3-18.

Staniland P (2012) States, insurgents, and wartime political orders. Perspectives on Politics 10(2): 243-264.

Stewart MA (2018) Civil war as state-making: strategic governance in civil war. International Organization 72(1): 205-226.

Tilly C (1990) Coercion, Capital, and European States, AD 990-1990. Cambridge: Blackwell.

Toal G (2017) Near Abroad: Putin, the West and the Contest Over Ukraine and the Caucasus. New York: Oxford University Press.

Walsh J, Conrad J and Whitaker BE (2018) Funding rebellion: the rebel contraband dataset. Journal of Peace Research 55(5): 699-707.

Weidmann NB (2016) A closer look at reporting bias in conflict event data. American Journal of Political Science 60(1): 206-218.

Weinstein JM (2007) Inside Rebellion: The Politics of Insurgent Violence. New York: Cambridge University Press.

Wickham-Crowley TP (1987) The rise (and sometimes fall) of guerrilla governments in Latin America. Sociological Forum 2(3): 473-499.

Zurcher C (2007) The Post-Soviet Wars: Rebellion, Ethnic Conflict, and Nationhood in the Caucasus. New York: New York University Press.

\section{Author biography}

Adrian Florea is lecturer/assistant professor in International Relations at the University of Glasgow (2015-), Scotland, UK. His main research interests are civil war, political violence, rebel governance, state (un)making, international security, and research methods. 